\title{
BMI, body fat and waist-to-height ratio of stunted $v$. non-stunted Indian children: a case-control study
}

\author{
Mitravinda S Savanur* and Padmini S Ghugre \\ Department of Food Science and Nutrition, Sir Vithaldas Vihar, SNDT Women's University, Juhu Road, \\ Mumbai - 400049, Maharashtra, India
}

Submitted 10 May 2015: Final revision received 15 December 2015: Accepted 22 January 2016: First published online 19 February 2016

\begin{abstract}
Objective: To compare the BMI, body fat and waist-to-height ratio (WHtR) of stunted and non-stunted children following different growth trajectories from low socio-economic strata in Mumbai, India.

Design: Cross-sectional, case-control study. Weight, height, skinfold thicknesses and waist circumference were measured. Information regarding the duration of breast-feeding, age at initiation of complementary feeding and income was obtained. Birth weight was obtained from records. BMI, body fat, WHtR and change in weight SD were calculated.

Setting: Children who were beneficiaries of anganwadis, Mumbai city, India.

Subjects: Three hundred and thirty children aged 2-4 years were selected in each of the stunted and non-stunted groups after matching for age and sex.

Results: After adjusting for birth weight, change in weight SD, duration of breastfeeding, age at complementary feeding initiation and income, stunted children had significantly higher body fat, WHtR and BMI than the non-stunted $(P<0 \cdot 01)$. The stunted and non-stunted children were classified based on their change in weight SD. Stunted children with no change in weight SD had higher mean body fat, BMI $(P<0.01)$ and WHtR $(P<0.05)$ than their non-stunted counterparts. In the catch-up growth group, stunted children had higher BMI and WHtR than the non-stunted (both $P<0 \cdot 001$ ). In the catch-down growth group, stunted children had higher BMI than the non-stunted $(P<0 \cdot 001)$.

Conclusions: Stunting was seen to increase the tendency of conserving body fat in young children. Such a tendency, if continued during later childhood and adolescence, can increase the risk of obesity and non-communicable diseases.
\end{abstract}

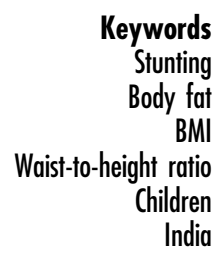

Globally, 171 million children (27\%) below 5 years of age were stunted in $2010^{(1)}$. The problem of stunting or chronic undernutrition is deeply rooted in poverty and deprivation, affecting mainly the developing and underdeveloped nations. Over the previous two decades, the prevalence of stunting in Asia has reduced by half from $48.6 \%$ to $27.6 \%$ in the years 1990 to $2010^{(1)}$. In comparison with the global rates, the prevalence of stunting in India is much higher (i.e. $48 \%$ ) with the rate in rural areas (50.7\%) exceeding that in urban ones $(39.6 \%)^{(2)}$. Stunting in early life is associated with short-term and long-term consequences. Stunting may hamper the structural and functional development of the brain, resulting in delayed cognitive function development or permanent cognitive impairment which may lead to poor academic achievement and low economic productivity $^{(3-5)}$. Childhood stunting is directly related to short adult stature and may have intergenerational effects.
Maternal stunting increases the risk for intra-uterine growth restriction, perinatal mortality, maternal mortality and undernutrition in the offspring ${ }^{(6)}$. In addition to this, early stunting is viewed as a risk factor for overweight and adiposity later in life.

Much of the evidence to support the relationship between stunting and obesity emerges from some cross-sectional studies that point towards a possible risk of overweight/ obesity among stunted children ${ }^{(7-11)}$ and adolescents ${ }^{(12-14)}$. Some studies have also shown that stunted children and adolescents have higher total body fat percentage (BF\%) and central adiposity ${ }^{(14-18)}$. Central adiposity has been independently associated with high levels of serum TAG, non-HDL cholesterol, fasting insulin, homeostatic model assessment of insulin resistance and C-reactive protein in young children $^{(19,20)}$. Further, Santos et al. ${ }^{(14)}$ found that adolescents with mild stunting and overweight had significantly 
higher blood glucose, insulin and homeostatic model assessment of insulin resistance $(P<0.05)$ than normalweight stunted ones. Also, Kruger et al. ${ }^{(17)}$ showed that stunted girls had higher TNF- $\alpha$ levels compared with nonstunted girls $(P=0 \cdot 03)$. These findings suggest that stunting at an early age can potentially increase the risk of overweight, glucose intolerance and dyslipidaemia.

To the best of our knowledge, there are no studies that have explored the relationship of stunting and adiposity among Indian children. There is a need to explore this relationship given that India has a high prevalence of stunting in young children ${ }^{(2)}$. Additionally, Indian infants and children possess a 'thin-fat' phenotype ${ }^{(21,22)}$. Adiposity in stunted children depends on the rate of weight gain during the early years. Rapid weight gain during infancy and childhood is a major risk factor for higher BMI, total body fat and central adiposity in later life ${ }^{(23)}$. Accelerated weight gain in childhood can be attributed to the rapid nutrition transition and limited facilities for physical activity present in India. Kimani-Murage et al. ${ }^{(9)}$ suggested that stunting and obesity may coexist in such transitional societies. All these factors in conjunction with each other predispose stunted children to overweight, thereby increasing the risk for non-communicable diseases.

We therefore conducted a case-control study with the objective to compare the $\mathrm{BMI}, \mathrm{BF} \%$ and waist-to-height ratio (WHtR) of stunted and non-stunted Indian children belonging to low socio-economic background following different growth trajectories.

\section{Materials and methods}

The study was approved by the Independent Ethics Committee (IEC no. 09122), Navi Mumbai, Maharashtra, India. Parents and/or guardians of the children received explanation about the study procedure in the local language and written informed consent was obtained from them.

\section{Study design}

We conducted a cross-sectional, case-control study in children aged 2-4 years belonging to low socio-economic sections in Mumbai city, India. Initially, we had conducted nutritional assessment of 1200 children aged 2-4 years from July 2013 to July 2014. From this initial group of children, we drew age- and sex-matched stunted (case) and non-stunted (control) children. Stunting was defined as height-for-age $Z$-score (HAZ) $\leq-2$. The non-stunted or control group included children with $\mathrm{HAZ} \geq-1 \cdot 5$. After matching for age and sex, the final sample included 330 stunted and 330 non-stunted children.

\section{Participants}

Children selected were beneficiaries of anganwadis, which are government-run mother-child care centres in
India. Date of birth of the children was obtained from either the anganwadi records or their birth certificates. Age was calculated on the basis of their date of birth to the nearest one month. Birth weight of the participants was obtained from discharge card of the hospital where the child was born or the anganwadi register.

\section{Measurements}

All of the following measurements were taken by the researcher in triplicate.

\section{Anthropometry}

Weight and height of all children were measured using a standard procedure ${ }^{(24)}$. Children were weighed on a digital weighing scale (model MS8270; Dr Gene Health and Wellness), with an accuracy of $0.1 \mathrm{~kg}$. Height was measured using a non-extensible, flexible measuring tape with an accuracy of $0.1 \mathrm{~cm}$ which was calibrated against the standard anthropometric scale. BMI was calculated.

\section{Body fat}

Harpenden callipers (Baty International, Burgess Hill, UK) were used to measure the skinfold thickness at triceps (TSF) and subscapular (SSF) sites ${ }^{(25)}$. BF\% was calculated using the equation given by Slaughter et al. ${ }^{(26)}$. Slaughter's equation has been reported to predict $\mathrm{BF} \%$ with high accuracy (95\%) and minimal bias, and has shown good precision compared with dual-energy X-ray absorptiometry in school-going children in Pakistan ${ }^{(27)}$.

\section{Measures of central fat}

Waist circumference (WC) and WHtR were used as indicators of central body fat ${ }^{(28-30)}$. WC has been associated with biomarkers of cardiovascular risk in children ${ }^{(20,31)}$. WHtR correlates strongly with $\mathrm{BF} \%$ and the distribution of body fat ${ }^{(32)}$. WC circumference was measured midway between the lowest rib margin (costal margin) and the superior anterior ileac crest with a non-extensible, flexible and accurate tape measure ${ }^{(33)}$.

\section{Change in weight sD}

Change in weight SD was calculated as follows: change in weight $\mathrm{SD}=$ present $\mathrm{WAZ}-\mathrm{WAZ}$ at birth, where WAZ is weight-for-age $Z$-score. Catch-up growth (CUG), catchdown growth (CDG) and 'no change in weight SD' were calculated $^{(34)}$. If change in weight SD was $>0.67$, then it was considered that the child showed CUG. On the other hand, if change in weight SD was $<-0.67$, then it was considered as CDG. If the change in weight SD was between -0.67 and +0.67 , then it was regarded as "no change in weight SD'.

\section{Child's feeding bistory}

Information about breast-feeding - total duration of breastfeeding, whether the child was exclusively breast-fed, 
duration of exclusive breast-feeding and the age at which complementary feeding was initiated - was obtained from the child's parent or guardian. In addition, details of income of all the family members were gathered to calculate the total family income.

\section{Statistical analysis}

HAZ and WAZ were computed using WHO Anthro software version $3 \cdot 2 \cdot 2$. The data were analysed using the statistical software package IBM SPSS Statistics Version 20. Mean and SD were calculated for continuous variables and frequency distribution for the categorical variables. One-way ANOVA was performed to see if there were any differences in mean anthropometry, BMI, TSF, SSF, BF\%, WC and WHtR between the two groups.

We carried out one-way ANCOVA to study the differences in BMI, BF\%, TSF, SSF, WC and WHtR after adjusting the means for certain confounding variables that may potentially influence the growth and nutritional status of the children. The analysis was adjusted for the following covariates: birth weight, change in weight SD, duration of exclusive breastfeeding, total duration of breast-feeding, age at initiation of complementary feeding and total family income. The stunted and non-stunted children were classified into the three categories of change in weight SD: CDG, no change in weight SD and CUG. We performed one-way ANCOVA to study the differences in BMI, BF\%, TSF, SSF, WC and WHtR between stunted and non-stunted groups who experienced CDG, no change in weight SD and CUG, independently, after adjusting the means for the studied covariates (birth weight, duration of exclusive breast-feeding, total duration of breast-feeding, age at initiation of complementary feeding and total family income).

\section{Results}

\section{Sample profile}

The characteristics of the sample are given in Table 1. Fiftythree per cent of the children were girls $(n$ 350) and $47 \%$ were boys ( $n$ 310) boys. The stunted group had a greater proportion of low-birth-weight children than the non-stunted group $(P=0 \cdot 001)$. A higher percentage of stunted children experienced CDG, while more non-stunted children showed CUG and no change in weight SD $(P=0 \cdot 000)$. In both groups, $>90 \%$ of the children received exclusive breast-feeding; however, the total duration of breast-feeding $(P=0.008)$ and that of exclusive breast-feeding $(P=0.029)$ were significantly higher among the stunted than the non-stunted children. The total family income of the stunted children was significantly lower than that of the non-stunted $(P=0.008)$.

\section{Anthropometry, BMI, body fat percentage, waist circumference and waist-to-beight ratio in stunted and non-stunted children}

The stunted boys and girls had significantly lower mean birth weight, present weight, height, HAZ and change in weight SD than their non-stunted counterparts (all $P<0 \cdot 05$; Table 2). Mean BMI, TSF, SSF, BF\% and WHtR were similar between the stunted and non-stunted boys and girls. Only stunted girls had a lower mean WC than the non-stunted girls $(P<0.05)$.

After adjusting for the covariates (birth weight, change in weight SD, duration of exclusive breast-feeding, total duration of breast-feeding, age at initiation of complementary feeding and total family income), stunted boys and girls were seen to have significantly higher $\mathrm{BF} \%$, TSF, SSF, BMI and WHtR than their non-stunted counterparts (all $P<0 \cdot 001$; Table 3 ). Stunted girls had significantly higher WC than the non-stunted girls $(P<0 \cdot 05)$. However, no such difference was noted in boys for WC.

\section{BMI, body fat percentage, waist circumference and waist-to-beight ratio in stunted and non-stunted children who had catch-down growth, no change in weight sD and catch-up growth}

After adjusting for the covariates, stunted children who had no change in weight SD had significantly higher mean BF\%, BMI (both $P<0.001)$ and WHtR $(P<0.05)$ than their non-stunted counterparts (Table 4). No differences were seen in mean WC measurements among them. In the CDG group, the stunted children had significantly higher BMI $(P<0 \cdot 001)$ than the non-stunted children. No differences were seen in mean values for $\mathrm{BF} \%, \mathrm{WC}$ and $\mathrm{WH}$ tR. On the other hand, in the CUG group, stunted children had significantly higher BMI and WHtR (both $P<0.001$ ) than the non-stunted children. Mean BF\% was higher in the stunted compared with the non-stunted children but the difference did not reach statistical significance.

\section{Discussion}

Our study is unique because it represents the first time that the BMI, BF\%, WC and WHtR of stunted children who experienced CUG, no change in weight SD and CDG in their early postnatal life have been compared with those of their respective non-stunted counterparts. In our study, almost $28 \%$ of stunted and $16 \%$ of non-stunted children had low birth weight. More than half of the stunted children experienced CDG while one-quarter showed CUG in their postnatal life. After adjusting for the covariates, the stunted children who experienced no change in weight SD had significantly higher BMI, BF\% and WHtR than the non-stunted ones. In the CUG group, stunted children had significantly higher BMI and WHtR than the non-stunted ones. Stunted children who had CDG had significantly higher BMI than their non-stunted counterparts.

Our findings of higher $\mathrm{BMI}, \mathrm{BF} \%$ and $\mathrm{WHtR}$ in stunted children with no change in weight SD are consistent with previous studies carried out in stunted children ${ }^{(8,10,11,16)}$. Studies have reported that the higher body fat in stunted children could possibly be due to a reduction in the 
Table 1 Characteristics of the sample of children aged 2-4 years from low socio-economic strata in Mumbai, India, July 2013-July 2014

\begin{tabular}{|c|c|c|c|c|c|c|}
\hline \multirow[b]{2}{*}{ Variable } & \multicolumn{2}{|c|}{ Non-stunted ( $n$ 330) } & \multicolumn{2}{|c|}{ Stunted ( $n$ 330) } & \multirow[b]{2}{*}{$x^{2}$} & \multirow[b]{2}{*}{$P$} \\
\hline & $\%$ & $n$ & $\%$ & $n$ & & \\
\hline \multicolumn{7}{|l|}{ Sex } \\
\hline Boys & $47 \cdot 0$ & 155 & $47 \cdot 0$ & 155 & \multirow[t]{2}{*}{0.000} & \multirow[t]{2}{*}{1.000} \\
\hline Girls & $53 \cdot 0$ & 175 & 53.0 & 175 & & \\
\hline \multicolumn{7}{|l|}{ Age } \\
\hline $2-3$ years & $50 \cdot 6$ & 167 & $50 \cdot 6$ & 167 & \multirow[t]{2}{*}{0.000} & \multirow[t]{2}{*}{1.000} \\
\hline $3-4$ years & $49 \cdot 4$ & 163 & $49 \cdot 4$ & 163 & & \\
\hline \multicolumn{7}{|l|}{ Birth weight } \\
\hline Low $(<2.5 \mathrm{~kg})$ & $16 \cdot 1$ & 53 & 27.9 & 92 & \multirow[t]{3}{*}{$13 \cdot 475$} & \multirow[t]{3}{*}{0.001} \\
\hline Normal $(2.5-3.9 \mathrm{~kg})$ & $82 \cdot 7$ & 273 & $71 \cdot 2$ & 231 & & \\
\hline High $(>4.0 \mathrm{~kg})$ & 1.2 & 4 & $0 . \overline{9}$ & 3 & & \\
\hline \multicolumn{7}{|l|}{ Change in weight SD } \\
\hline Catch-down growth $(<-0.67)$ & $20 \cdot 0$ & 66 & 58.5 & 193 & \multirow{3}{*}{$109 \cdot 492$} & \multirow[t]{3}{*}{0.000} \\
\hline No change $(-0.67 \text { to }+0.67)^{\prime}$ & $42 \cdot 7$ & 141 & $28 \cdot 2$ & 93 & & \\
\hline Catch-up growth $(>0.67)$ & $37 \cdot 3$ & 123 & $13 \cdot 3$ & 44 & & \\
\hline \multicolumn{7}{|l|}{ Exclusive breast-feeding } \\
\hline \multirow{3}{*}{$\begin{array}{l}\text { Yes } \\
\text { No }\end{array}$} & 91.5 & 301 & 92.4 & 305 & \multirow[t]{2}{*}{0.670} & \multirow[t]{2}{*}{0.383} \\
\hline & 8.5 & 29 & $7 \cdot 6$ & 25 & & \\
\hline & Mean & SD & Mean & SD & $F$ & $P$ \\
\hline Duration of exclusive breast-feeding (months) & 4.9 & $2 \cdot 7$ & 5.5 & 3.7 & 4.767 & 0.029 \\
\hline Total duration of breast-feeding (months) & $20 \cdot 1$ & $10 \cdot 0$ & $22 \cdot 2$ & $10 \cdot 4$ & $7 \cdot 157$ & 0.008 \\
\hline Age at the initiation of complementary feeding (months) & 7.4 & $3 \cdot 8$ & 7.9 & 4.6 & $3 \cdot 180$ & 0.075 \\
\hline Total family income (Indian Rs) & 14475 & 10263 & 12523 & 8367 & $7 \cdot 172$ & 0.008 \\
\hline
\end{tabular}

Table 2 Unadjusted mean anthropometric parameters, BMI, skinfold thickness, WC, WHtR, BF\% and change in weight SD in stunted and non-stunted boys and girls aged 2-4 years from low socio-economic strata in Mumbai, India, July 2013-July 2014

\begin{tabular}{|c|c|c|c|c|c|c|c|c|c|c|c|c|c|c|c|}
\hline \multirow[b]{3}{*}{ Parameter } & \multicolumn{5}{|c|}{ Boys } & \multicolumn{5}{|c|}{ Girls } & \multicolumn{5}{|c|}{ Total } \\
\hline & \multicolumn{2}{|c|}{$\begin{array}{l}\text { Non-stunted } \\
\quad(n \text { 155) }\end{array}$} & \multicolumn{2}{|c|}{$\begin{array}{l}\text { Stunted } \\
(n \text { 155) }\end{array}$} & \multirow[b]{2}{*}{$F$} & \multicolumn{2}{|c|}{$\begin{array}{l}\text { Non-stunted } \\
\quad(n \text { 175) }\end{array}$} & \multicolumn{2}{|c|}{$\begin{array}{l}\text { Stunted } \\
(n \text { 175) }\end{array}$} & \multirow[b]{2}{*}{$F$} & \multicolumn{2}{|c|}{$\begin{array}{l}\text { Non-stunted } \\
\quad(n 330)\end{array}$} & \multicolumn{2}{|c|}{$\begin{array}{l}\text { Stunted } \\
(n 330)\end{array}$} & \multirow[b]{2}{*}{$F$} \\
\hline & Mean & SD & Mean & SD & & Mean & SD & Mean & SD & & Mean & SD & Mean & SD & \\
\hline Birth weight (kg) & 2.87 & 0.48 & 2.59 & 0.59 & $19 \cdot 848^{* *}$ & $2 \cdot 70$ & 0.48 & 2.59 & 0.49 & $4 \cdot 875^{\star}$ & $2 \cdot 78$ & 0.50 & 2.59 & 0.50 & $22 \cdot 334^{* *}$ \\
\hline Weight $(\mathrm{kg})$ & $13 \cdot 1$ & $1 \cdot 6$ & $10 \cdot 6$ & 1.2 & $226 \cdot 902^{\star \star}$ & $12 \cdot 2$ & 1.8 & $10 \cdot 2$ & 1.2 & $166 \cdot 836^{\star \star}$ & $12 \cdot 6$ & 1.7 & $10 \cdot 4$ & $1 \cdot 2$ & $370 \cdot 127^{\star \star}$ \\
\hline Height (cm) & $94 \cdot 2$ & $5 \cdot 1$ & 84.9 & $4 \cdot \overline{7}$ & $273.916^{\star \star}$ & 92.5 & $5 \cdot 2$ & 83.9 & $5 \cdot 0$ & $239 \cdot 196^{\star \star}$ & 93.3 & $5 \cdot 2$ & 84.4 & 4.9 & $500 \cdot 950^{\star *}$ \\
\hline HAZ & -0.41 & 0.70 & -2.85 & 0.60 & $884 \cdot 271^{\star \star}$ & -0.59 & 0.70 & -2.79 & 0.66 & $903.860^{\star \star}$ & -0.51 & 0.73 & $-2 \cdot 82$ & 0.66 & $1777.056^{\star \star}$ \\
\hline BMI $\left(\mathrm{kg} / \mathrm{m}^{2}\right)$ & $14 \cdot 7$ & $1 \cdot 1$ & $14 \cdot 7$ & 1.2 & 0.145 & $14 \cdot 3$ & 1.4 & $14 \cdot 4$ & $1 \cdot 1$ & 0.697 & 14.5 & 1.3 & 14.5 & $1 \cdot 2$ & 0.136 \\
\hline TSF $(\mathrm{mm})$ & 7.5 & 1.4 & 7.4 & 1.3 & 0.402 & $7 \cdot 6$ & 1.6 & 7.4 & 1.3 & 1.295 & 7.5 & 1.5 & 7.4 & 1.3 & 1632 \\
\hline $\mathrm{SSF}(\mathrm{mm})$ & $5 \cdot 2$ & 1.0 & 4.9 & 0.8 & 5.075 & 5.4 & 1.4 & $5 \cdot 2$ & 1.0 & 2.942 & $5 \cdot 3$ & 1.3 & $5 \cdot 1$ & 0.9 & $7 \cdot 324^{\star}$ \\
\hline WC $(\mathrm{cm})$ & 48.4 & $2 \cdot 6$ & $46 \cdot 4$ & $6 \cdot 6$ & 32.085 & $47 \cdot 6$ & $6 \cdot 2$ & 44.5 & $8 \cdot 1$ & $16 \cdot 328^{\star \star}$ & $48 \cdot 0$ & 4.8 & $44 \cdot 4$ & 8.2 & $45 \cdot 190^{* *}$ \\
\hline WHtR & 0.51 & 0.03 & 0.52 & $0 \cdot 10$ & 0.651 & 0.51 & 0.06 & 0.53 & 0.09 & $2 \cdot 401$ & 0.52 & 1.00 & 0.52 & 0.07 & 2.914 \\
\hline $\mathrm{BF} \%$ & $12 \cdot 4$ & $2 \cdot 3$ & $12 \cdot 1$ & 1.9 & 1.906 & $12 \cdot 6$ & $2 \cdot 7$ & $12 \cdot 2$ & $2 \cdot 2$ & 1.466 & 12.5 & $2 \cdot 5$ & $12 \cdot 1$ & $2 \cdot 1$ & $3 \cdot 278$ \\
\hline Change in weight SD & 0.32 & $1 \cdot 24$ & -0.69 & 1.35 & $47 \cdot 812^{\star \star}$ & 0.28 & 1.29 & -0.88 & 1.32 & $70 \cdot 345^{\star \star}$ & 0.30 & $1 \cdot 26$ & -0.79 & 1.33 & $117 \cdot 743^{\star *}$ \\
\hline
\end{tabular}

WC, waist circumference; WHtR, waist-to-height ratio; BF\%, body fat percentage; HAZ, height-for-age Z-score; TSF, triceps skinfold; SSF, subscapular skinfold. ${ }^{\star} P<0.05,{ }^{\star \star} P<0.001$.

oxidation of fat in these children ${ }^{(35,36)}$. The RQ indicates the substrate being used for energy production. In one study, stunted children had a significantly higher RQ (0.92 (SD 0.009)) than control children (0.89 (SD 0.007)). A higher $\mathrm{RQ}$ means that the chief substrate for metabolism is carbohydrate (RQ of carbohydrate $=1$ ). Stunted children derived $25 \%$ energy from fat oxidation while the controls obtained significantly higher energy (i.e. $34 \%$ ) from oxidation of fat ${ }^{(35)}$. Evidence also suggests that chronic starvation or undernutrition results in a reduction in total energy expenditure (i.e. RMR, sleeping metabolic rate and physical activity). This is believed to be because the depleted fat stores activate an autoregulatory feedback mechanism that suppresses thermoregulation ${ }^{(37,38)}$. Thus during prolonged starvation or periods of undernutrition the body adapts to lower energy expenditure which improves the metabolic efficiency. Further, Sawaya et $a l^{(39)}$ suggested that long-term undernutrition is accompanied by lower circulating levels of insulin-like growth factor-1. Low insulin-like growth factor-1 levels are associated with lower insulin levels and higher ratios of cortisol to insulin. High cortisol levels are associated with 
Table 3 Adjusted mean BMI, BF\%, skinfold thickness, WC and WHtR in stunted and non-stunted boys and girls aged 2-4 years from low socio-economic strata in Mumbai, India, July 2013-July 2014

\begin{tabular}{|c|c|c|c|c|c|c|c|c|c|c|c|c|c|c|c|}
\hline \multirow[b]{3}{*}{ Parameter } & \multicolumn{5}{|c|}{ Boys } & \multicolumn{5}{|c|}{ Girls } & \multicolumn{5}{|c|}{ Total } \\
\hline & \multicolumn{2}{|c|}{$\begin{array}{l}\text { Non-stunted } \\
\quad(n \text { 155) }\end{array}$} & \multicolumn{2}{|c|}{$\begin{array}{l}\text { Stunted } \\
(n \text { 155) }\end{array}$} & \multirow[b]{2}{*}{$F$} & \multicolumn{2}{|c|}{$\begin{array}{l}\text { Non-stunted } \\
\quad(n \text { 175) }\end{array}$} & \multicolumn{2}{|c|}{$\begin{array}{l}\text { Stunted } \\
(n \text { 175) }\end{array}$} & \multirow[b]{2}{*}{$F$} & \multicolumn{2}{|c|}{$\begin{array}{l}\text { Non-stunted } \\
\quad(n 330)\end{array}$} & \multicolumn{2}{|c|}{$\begin{array}{l}\text { Stunted } \\
(n 330)\end{array}$} & \multirow[b]{2}{*}{$F$} \\
\hline & Mean† & SE & Mean† & SE & & Mean† & SE & Mean† & SE & & Mean† & SE & Mean† & SE & \\
\hline $\mathrm{BMI}\left(\mathrm{kg} / \mathrm{m}^{2}\right)$ & $13 \cdot 7$ & 0.079 & $15 \cdot 7$ & 0.079 & $211 \cdot 112^{\star *}$ & $13 \cdot 4$ & 0.070 & $15 \cdot 4$ & 0.070 & $311.738^{\star *}$ & 13.6 & 0.052 & $15 \cdot 3$ & 0.052 & $529.860^{\star \star}$ \\
\hline BF\% & 11.4 & 0.195 & $13 \cdot 1$ & 0.195 & $27.550^{\star *}$ & 11.4 & 0.192 & 13.4 & 0.192 & $40 \cdot 194^{\star *}$ & 11.5 & 0.138 & $13 \cdot 2$ & 0.138 & $59 \cdot 193^{\star \star}$ \\
\hline TSF $(\mathrm{mm})$ & 6.9 & 0.129 & 7.9 & 0.129 & $22.392^{\star \star}$ & 7.0 & 0.119 & 8.0 & 0.119 & $30.833^{\star \star}$ & $7 \cdot 0$ & 0.087 & 8.0 & 0.087 & $49.006^{\star *}$ \\
\hline SSF $(\mathrm{mm})$ & 4.7 & 0.090 & 5.4 & 0.090 & $21 \cdot 476^{\star \star}$ & 4.8 & 0.092 & 5.9 & 0.092 & $54.675^{\star *}$ & 4.8 & 0.066 & $5 \cdot 6$ & 0.066 & $59.685^{\star \star}$ \\
\hline$W C(\mathrm{~cm})$ & $46 \cdot 7$ & 0.611 & $46 \cdot 1$ & 0.611 & 0.296 & 45.0 & 0.591 & 47.0 & 0.591 & $4.018^{\star}$ & $45 \cdot 8$ & 0.424 & $46 \cdot 6$ & 0.424 & 1.343 \\
\hline WHtR & 0.50 & 0.007 & 0.53 & 0.007 & $6.405^{\star *}$ & 0.49 & 0.007 & 0.55 & 0.007 & $29.982^{\star *}$ & 0.49 & 0.005 & 0.54 & 0.005 & $32.879^{\star *}$ \\
\hline
\end{tabular}

BF\%, body fat percentage; WC, waist circumference; WHtR, waist-to-height ratio; TSF, triceps skinfold; SSF, subscapular skinfold.

${ }^{\star} P<0.05,{ }^{\star \star} P<0.001$.

†Means adjusted for birth weight, change in weight SD, duration of exclusive breast-feeding, total duration of breast-feeding, age at initiation of complementary feeding and total family income.

Table 4 Adjusted mean BMI, BF\%, skinfold thickness, WC and WHtR across the change in weight sD categories in non-stunted and stunted children aged 2-4 years from low socio-economic strata in Mumbai, India, July 2013-July 2014

\begin{tabular}{|c|c|c|c|c|c|c|c|c|c|c|c|c|c|c|c|}
\hline \multirow[b]{3}{*}{ Parameter } & \multicolumn{5}{|c|}{ CDG } & \multicolumn{5}{|c|}{ No change in weight SD } & \multicolumn{5}{|c|}{ CUG } \\
\hline & \multicolumn{2}{|c|}{$\begin{array}{l}\text { Non-stunted } \\
\quad(n 66)\end{array}$} & \multicolumn{2}{|c|}{$\begin{array}{l}\text { Stunted } \\
(n 193)\end{array}$} & \multirow[b]{2}{*}{$F$} & \multicolumn{2}{|c|}{$\begin{array}{l}\text { Non-stunted } \\
\quad(n 141)\end{array}$} & \multicolumn{2}{|c|}{$\begin{array}{l}\text { Stunted } \\
(n 93)\end{array}$} & \multirow[b]{2}{*}{$F$} & \multicolumn{2}{|c|}{$\begin{array}{l}\text { Non-stunted } \\
\quad(n 123)\end{array}$} & \multicolumn{2}{|c|}{$\begin{array}{l}\text { Stunted } \\
(n \text { 44) }\end{array}$} & \multirow[b]{2}{*}{$F$} \\
\hline & Mean† & SE & Meant & SE & & Mean† & SE & Meant & SE & & Mean† & SE & Mean† & SE & \\
\hline BMI $\left(\mathrm{kg} / \mathrm{m}^{2}\right)$ & $13 \cdot 9$ & 0.103 & $14 \cdot 3$ & 0.068 & $8 \cdot 176^{\star *}$ & $13 \cdot 9$ & 0.071 & $15 \cdot 5$ & 0.090 & $166 \cdot 115^{\star \star}$ & $14 \cdot 7$ & 0.124 & $15 \cdot 8$ & 0.232 & $14 \cdot 249^{* *}$ \\
\hline $\mathrm{BF} \%$ & 11.9 & 0.212 & $12 \cdot 1$ & 0.143 & 1.109 & 11.9 & 0.182 & $13 \cdot 2$ & 0.233 & $16 \cdot 379^{\star \star}$ & $12 \cdot 6$ & 0.243 & $13 \cdot 4$ & 0.454 & 1.801 \\
\hline TSF $(\mathrm{mm})$ & $7 \cdot 2$ & 0.127 & $7 \cdot 3$ & 0.085 & 0.703 & 7.4 & 0.120 & 8.0 & 0.154 & $9 \cdot 278^{\star \star}$ & $7 \cdot 6$ & 0.153 & 8.1 & 0.285 & 1.915 \\
\hline $\mathrm{SSF}(\mathrm{mm})$ & 5.1 & 0.092 & 5.0 & 0.062 & 1.023 & 4.9 & 0.085 & 5.7 & 0.108 & $22 \cdot 413^{\star \star}$ & 5.5 & 0.131 & $5 \cdot 8$ & 0.245 & 1.501 \\
\hline WC $(\mathrm{cm})$ & 44.7 & 0.713 & 44.5 & 0.475 & 0.317 & $47 \cdot 2$ & 0.574 & $46 \cdot 0$ & 0.735 & 1.339 & $48 \cdot 1$ & 0.557 & $47 \cdot 8$ & 0.104 & 0.063 \\
\hline $\mathrm{WH} \mathrm{tR}$ & 0.51 & 0.008 & 0.52 & 0.006 & 1.296 & 0.51 & 0.007 & 0.54 & 0.009 & $4.333^{*}$ & 0.51 & 0.007 & 0.57 & 0.012 & $11.776^{\star \star}$ \\
\hline
\end{tabular}

BF\%, body fat percentage; WC, waist circumference; WHtR, waist-to-height ratio; CDG, catch-down growth; CUG, catch-up growth; TSF, triceps skinfold; SSF, subscapular skinfold.

${ }^{\star} P<0.05,{ }^{\star \star} P<0.001$.

†Means adjusted for birth weight, duration of exclusive breast-feeding, total duration of breast-feeding, age at initiation of complementary feeding and total family income.

central fat deposition. This may explain the higher WHtR found in stunted children than their non-stunted counterparts who experienced no change in weight SD in the present study. Thus, previously undernourished individuals develop a tendency to conserve more body fat particularly, abdominal fat.

We found that stunted children who experienced CUG had higher BMI and WHtR than the non-stunted ones. During recovery from starvation, owing to the improved metabolic efficiency, the body conserves energy and accumulates more body fat. This tendency is referred to as 'metabolic adaptation' or 'poststarvation obesity ${ }^{\text {(40) }}$. In a prospective study, Grillo et $a l^{(41)}$ found that stunted children gained $6 \mathrm{~kg} /$ year while the non-stunted children maintained at $4 \mathrm{~kg} /$ year irrespective of both groups consuming similar diets. This was because during the follow-up period there was a lesser increase in RMR but a greater increase in the velocity of weight gain in the stunted group compared with the non-stunted group. The stunted girls had lower body fat at the beginning of the study but gained more fat than the non-stunted ones after 36 months. Thus, infants and children recovering from undernutrition disproportionately accumulate more fat than muscle mass during CUG. In the present study, the stunted children who exhibited CUG had higher mean BF\% than the non-stunted group but the difference was not significant.

Stunted children who had CDG had higher BMI than their non-stunted counterparts. However, they did not show much difference in their body fat indices compared with the non-stunted. CDG represents growth faltering or a period of undernutrition. It appears that both stunted and non-stunted children who experienced growth faltering would have equally adapted to lower energy expenditure to improve metabolic efficiency. This may explain the similar BF\%, WC and WHtR values in both these groups.

In addition to adaptation, body composition depends on the quality of the diet and the level of physical activity. Although we did not carry out a detailed dietary 
assessment, surveys carried out in Indian urban low- to middle-income groups have shown an increase in the consumption of energy-dense foods among children ${ }^{(42-45)}$. Bentley et $a l .{ }^{(45)}$ found that in informal settlements of Mumbai, the diets of children under 5 years of age were marked by consumption of unhealthy snacks. This pattern was seen from infancy and increased during childhood years. The low per unit cost of the snacks made it an easier and a more convenient option for parents to include in their children's daily diet. Researchers have noted a similar unhealthy dietary pattern in overweight/obese stunted children $^{(7,46,47)}$. Based on four large nationwide surveys from Russia, China, South Africa and Brazil in children aged 3-6 years and 7-10 years old, Popkin et al. ${ }^{(7)}$ noted that stunted children were likely to become overweight or have abdominal obesity when exposed to energy-dense, high-fat foods along with moderate physical activity. SaidMohammad et al. ${ }^{(46)}$ observed that children who were only stunted and those who were stunted plus overweight spent more time in sedentary activities than the only overweight children. Also, the dietary diversity scores of the stunted plus overweight children were significantly lower than those of the only overweight group $(P<0 \cdot 01)$. Li et $a l^{(47)}$ added that children who were stunted and stunted plus overweight consumed more energy-dense foods and less protein, PUFA, Fe, fruits and vegetables. Sawaya et $a l{ }^{(39)}$ observed in mildly stunted girls that baseline fat intake level positively correlated with the rise in weight-forheight after 22 months ( $P=0 \cdot 048)$. This means that stunted girls gained more weight for the corresponding height compared with non-stunted girls.

Contrary to the findings of Sawaya et al. ${ }^{(39)}$, Tanner et $a l .{ }^{(48)}$ reported that adolescents who were stunted at the age of 2 years were less likely to be overweight than those who were never stunted in a longitudinal study in 'Tsimani', an indigenous group residing in the Beni Department of Bolivia, South America. These participants belonged to families who earned their living primarily by agriculture and supplemented it with hunting and gathering. They depended wholly on crops grown at household level and domestic animals for food. Also, these children/adolescents actively participated in hunting, farming, fishing and assisting the elders in their work. Thus, diet and physical activity do influence the body composition in stunted children.

India is witnessing a rapid economic, social and nutritional transition. Urban areas are noticing a rise in the population density leading to poor living conditions. At the same time, there has been a shift from traditional foods to the consumption of energy-dense foods rich in fat and carbohydrates. This shift is evident across the socioeconomic classes. Indians also possess a thin-fat phenotype from an early age that predisposes them to adverse metabolic outcomes ${ }^{(21)}$. Thus, impoverished living conditions coupled with easy availability of low-cost energy-dense foods and lesser scope for physical activity in areas with high prevalence of stunting elevate the risk of adiposity in Indians during recovery from undernutrition. However, CUG is imperative in stunted children. This CUG should be achieved with a healthy balance between adequate nutrition and physical activity.

\section{Conclusions and recommendations}

The present study is one of the first in India to have compared the body fat indices between stunted and non-stunted children belonging to low socio-economic background following different growth trajectories. Our findings suggest that stunted children with no change in weight, CDG and CUG have higher body fat indices than their non-stunted counterparts. Postnatal growth trajectory influences the change in body fat. Urbanization, nutrition transition and poor physical activity can potentially increase the risk of adiposity in stunted children as they grow older. Growth during childhood and adolescence is accompanied by changes in body composition. In view of this, longitudinal studies should be undertaken in India to map the changes in body composition during childhood/ adolescence in stunted children across the socio-economic strata. Also, there is a need for preventive measures to reduce the prevalence of stunting. Strategies to increase physical activity and improve dietary quality should be in place to achieve optimal growth without increasing the risk for adiposity in stunted children.

\section{Acknowledgements}

Acknowledgements: The authors thank the Independent Ethics Committee, Navi Mumbai, India for granting the ethical clearance to conduct the study. They acknowledge the continuous support and cooperation of the child development project officers, anganwadi workers and helpers. Financial support: This work received no specific grant from any funding agency in the public, commercial or not-for-profit sectors. Conflict of interest: None. Authorship: M.S.S. and P.S.G. conceptualized the study. M.S.S. collected and analysed the data and prepared the manuscript draft. P.S.G. provided critical inputs in the analysis and manuscript preparation. Ethics of human subject participation: The study was approved by Independent Ethics Committee (IEC no. 09122), Navi Mumbai, Maharashtra, India.

\section{References}

1. de Onis M, Blössner M \& Borghi E (2012) Prevalence and trends of stunting among pre-school children, 1990-2020. Public Health Nutr 15, 142-148.

2. International Institute for Population Sciences \& Macro International (2007) National Family Health Survey (NFHS-3), 2005-06: India: Volume I. Mumbai: IIPS.

3. Kar BR, Rao SL \& Chandramouli BA (2008) Cognitive development in children with chronic protein energy malnutrition. Behav Brain Funct 4, 31. 
4. Duc LT (2009) The Effect of Early Age Stunting on Cognitive Achievement Among Children in Vietnam. Oxford: Young Lives, Department of International Development, University of Oxford.

5. Sokolovic N, Selvam S, Srinivasan K et al. (2014) Catch-up growth does not associate with cognitive development in Indian school-age children. Eur J Clin Nutr 68, 14-18.

6. Dewey KG \& Begum K (2011) Long-term consequences of stunting in early life. Matern Child Nutr 7, 5-18.

7. Popkin BM, Richards MK \& Montiero CA (1996) Stunting is associated with overweight in children of four nations that are undergoing the nutrition transition. I Nutr $\mathbf{1 2 6}$, 3009-3016.

8. El Taguri A, Besmar F, Abdel Monem A et al. (2009) Stunting is a major risk factor for overweight: results from national surveys in 5 Arab countries. East Mediterr Health $J \mathbf{1 5}$, 549-562.

9. Kimani-Murage EW, Kahn K, Pettifor JM et al. (2010) The prevalence of stunting, overweight and obesity, and metabolic disease risk in rural South African children. $B M C$ Public Health 10, 158.

10. Bacardi-Gascon M, Jimnez-Moran E, Santillana-Marin E et al. (2012) High increments of overweight along with low length-for-age growth during the first 24 months of life. Nutr Hosp 27, 1894-1899.

11. Pomeroy E, Stock JT, Stanojevic S et al. (2014) Stunting, adiposity, and the individual-level 'dual burden' among urban lowland and rural highland Peruvian children. Am J Hum Biol 26, 481-490.

12. Bénéfice E, Garnier D, Simondon KB et al. (2001) Relationship between stunting in infancy and growth and fat distribution during adolescence in Senegalese girls. Eur J Clin Nutr 55, 50-58.

13. Sichieri R, Dos Santos Barbosa F \& Moura EC (2010) Relationship between short stature and obesity in Brazil: a multilevel analysis. Br J Nutr 103, 1534-1538.

14. Santos CDDL, Clemente APG, Martins VJB et al. (2010) Adolescents with mild stunting show alterations in glucose and insulin metabolism. I Nutr Metab 2010, 943070.

15. Martins PA, Hoffman DJ, Fernandes MTB et al. (2004) Stunted children gain less lean body mass and more fat mass than their non-stunted counterparts: a prospective study. BrJ Nutr 92, 819-825.

16. Hoffman DJ, Martins PA, Roberts SB et al. (2007) Body fat distribution in stunted compared with normal-height children from the shantytowns of São Paulo, Brazil. Nutrition 23, 640-646.

17. Kruger HS, Pretorius R \& Schette AE (2010) Stunting, adiposity and low-grade inflammation in African adolescents from a township high school. Nutrition 26, 90-99.

18. Clemante APG, da Luz Santos CD, Martins VJB et al. (2011) Mild stunting is associated with higher body fat: study of a low-inome population. J Pediatr (Rio J) 87, 138-144.

19. Corvalán C, Gregory CO, Ramirez-Zea M et al. (2007) Size at birth, infant, early and later childhood growth and adult body composition: a prospective study in a stunted population. Int J Epidemiol 36, 550-557.

20. Messiah SE, Arheart KL, Natale RA et al. (2012) BMI, waist circumference, and selected cardiovascular disease risk factors among preschool-age children. Obesity (Silver Spring) 20, 1942-1949.

21. Krishnaveni G, Hill J, Veena S et al. (2005) Truncal adiposity is present at birth and in early childhood in South Indian children. Indian Pediatr 42, 527-538.

22. Yajnik CS, Lubree HG, Rege SS et al. (2002) Adiposity and hyperinsulinemia in Indians are present at birth. I Clin Endocrinol Metab 87, 5575-5580.

23. Dulloo AG (2008) Thrifty energy metabolism in catch-up growth trajectories to insulin and leptin resistance. Best Pract Res Clin Endocrinol Metab 22, 155-171.
24. Fidanza F \& Keller W (1991) Anthropometric methodology. In Nutritional Status Assessment: A Manual for Population Studies, pp. 6-11 [F Fidanza, editor]. London: Chapman \& Hall.

25. Norgan N, Fidanza F \& Sarchielli P (1991) Anthropometric methodology. In Nutritional Status Assessment: A Manual for Population Studies, pp. 29-39 [F Fidanza, editor]. London: Chapman \& Hall

26. Slaughter MH, Lohman TG, Boileau RA et al. (1988) Skinfold equations for estimation of body fatness in children and youth. Hum Biol 60, 709-723.

27. Hussain Z, Jafar T, Zaman MU et al. (2014) Correlations of skin fold thickness and validation of prediction equations using DEXA as the gold standard for estimation of body fat composition in Pakistani children. BMJ Open 4, e004194.

28. Van der Kooy K, Leenen $\mathrm{R}$ et al. (1993) Abdominal diameters as indicators of visceral fat: comparison between magnetic resonance imaging and anthropometry. Br J Nutr 70, 47-58

29. Weili Y, He B, Yao H et al. (2007) Waist-to-height ratio is an accurate and easier index for evaluating obesity in children and adolescents. Obesity (Silver Spring) 15, 748-752.

30. Mokha JS, Srinivasan SR, Dasmahapatra P et al. (2010) Utility of waist-to-height ratio in assessing the status of central obesity and related cardiometabolic risk profile among normal weight and overweight/obese children: the Bogalusa Heart Study. BMC Pediatrics 10, 73.

31. Kuriyan R, Thomas T, Lokesh DP et al. (2011) Waist circumference and waist for height percentiles in urban South Indian children aged 3-16 years. Indian Pediatr $\mathbf{4 8}$, $765-771$.

32. Nambiar S, Hughes I \& Davies PS (2010) Developing waist-to-height ratio cut-offs to define overweight and obesity in children and adolescents. Public Health Nutr $\mathbf{1 3}$, 1566-1574.

33. Seidell J (1991) Anthropometric methodology. In Nutritional Status Assessment: A Manual for Population Studies, pp. 24-28 [F Fidanza, editor]. London: Chapman \& Hall.

34. Ong KKL, Ahmed ML, Emmett PM et al. (2000) Association between postnatal catchup growth and obesity in childhood: prospective cohort study. BMJ 320, 967-971.

35. Hoffman DJ, Sawaya AL, Verreschi I et al. (2000) Why are nutritionally stunted children at risk of obesity? Studies of metabolic rate and fat oxidation in shanytown children from Sao Paulo, Brazil. Am J Clin Nutr 72, 702-707.

36. Sawaya AL \& Roberts S (2003) Stunting and future risk of obesity: principal physiological mechanisms. Cad Saude Publica 19, Suppl. 1, S21-S28.

37. Dullo AG \& Jacquet J (1998) Adaptive reduction in basal metabolic rate in response to food deprivation in humans: a role for feedback signals from fat stores. Am J Clin Nutr $\mathbf{6 8}$, 599-606.

38. Dullo AG, Jacquet J \& Girardier L (1997) Poststarvation hyperphagia and body fat overshooting in humans: a role for feedback signals from lean and fat tissues. Am J Clin Nutr 65, 717-723.

39. Sawaya AL, Grillo LP, Verreschi I et al. (1998) The effects of childhood diet on adult health and disease mild stunting is associated with higher susceptibility to the effects of high fat diets: studies in a Shantytown population in Sao Paulo, Brazil. J Nutr 128, 2 Suppl., 415S-420S.

40. Keys A, Brozek J, Henschel A et al. (1950) The Biology of Human Starvation. Minneapolis, MN: University of Minnesota Press.

41. Grillo LP, Siqueira AFA, Silva AC et al. (2005) Lower resting metabolic rate and higher velocity of weight gain in a prospective study of stunted vs nonstunted girls living in the shantytowns of Sao Paulo, Brazil. Eur J Clin Nutr 59, 835-842.

42. Pingali P \& Khwaja Y (2004) Globalisation of Indian Diets and the Transformation of Food Supply Systems: Inaugural 
Keynote Address, 17th Annual Conference, Indian Society of Agricultural Marketing, Hyderabad, 5-7 February 2004. ESA Working Paper no. 04-05. Rome: FAO.

43. Kapur D, Sharma S \& Agarwal KN (2005) Dietary intake and growth pattern of children 9-36 months of age in an urban slum in Delhi. Indian Pediatr 42, 351-356.

44. Kuriyan R, Thomas T, Sumithra S et al. (2012) Potential factors related to waist circumference in urban South Indian children. Indian Pediatr 49, 124-128.

45. Bentley A, Das S, Alcock G et al. (2015) Malnutrition and infant and young child feeding in informal settlements in Mumbai, India: findings from a census. Food Sci Nutr 3, 257-271.
46. Said-Mohamed R, Bernard JY, Ndzana AC et al. (2012). Is overweight in stunted preschool children in Cameroon related to reductions in fat oxidation, resting energy expenditure and physical activity? PLoS One 7, e39007.

47. Li Y, Wedick NM, Lai J et al. (2011) Lack of dietary diversity and dyslipidaemia among stunted overweight children: the 2002 China National Nutrition and Health Survey. Public Health Nutr 14, 896-903.

48. Tanner S, Leonard WR, Reyes-Garcia V et al. (2014) The consequences of linear growth stunting: Influence on body composition among youth in the Bolivian Amazon. Am J Phys Anthropol 153, 92-102. 